\title{
UTJECAJ TERORISTIČKIH NAPADA NA PRILJEV IZRAVNIH STRANIH ULAGANJA U TRANZICIJSKIM ZEMLJAMA
}

\author{
Tomislav Galović ${ }^{11}$
}

UDK / UDC: 323.28:339.727.22(4-69)

JEL klasifikacija / JEL classification: F2, G24

DOI: https://doi.org/10.22598/pi-be/2019.13.2.111

Prethodno priopćenje / Preliminary communication

Primljeno / Received: 17. srpnja 2019. / July 17, 2019

Prihvaćeno za tisak / Accepted for publishing: 11. studenog 2019. / November 11,2019

\section{Sažetak}

Osnovni cilj rada je empirijski izmjeriti utjecaj terorizma $i$ ostalih (institucionalnih, ekonomskih prirodnih) čimbenika na zalihe izravnih stranih ulaganja (FDI) tranzicijskih zemalja svijeta. Metodologija podrazumijeva primjenu sistemskog GMM procjenitelja (Generalized Method of Moments) $u$ dva koraka dinamičke panel analize. Istraživanje obuhvaća grupu od 16 zemalja od 2000 do 2016. godine. Rezultati istraživanja potvrđuju kako teroristički incidenti, ekonomske i institucionalne varijable utječu na zalihe FDI-ja tranzicijskih zemalja globalnog gospodarstva. Može se zaključiti kako su institucionalne varijable (učinkovitost vlade, borba protiv korupcije) zabilježile najznačajniji utjecaj na zalihe FDI-ja u tranzicijskim zemljama globalnog gospodarstva. Iz rezultata se može vidjeti kolika je međunarodna konkurentnost tranzicijskih zemalja u pogledu utjecaja varijable terorizma $i$ ostalih relevantnih varijabli modela na izravna strana ulaganja (FDI).

Ključne riječi: FDI, konkurentnost, tranzicijske zemlje, terorizam, GMM procjenitelj.

\footnotetext{
* Rad je financijski podržan od strane Sveučilišta u Rijeci pod projektnim brojem uniridrustv-18-16.

11 Dr. sc. Tomislav Galović, Izvanredni profesor, Sveučilište u Rijeci, Ekonomski fakultet, Ivana Filipovića 4, 51000 Rijeka, Republika Hrvatska, E-mail: tomislav.galovic@efri.hr
} 


\section{UVOD}

Jedna od aktualnih, ali i nedovoljno istraženih tema jest terorizam i njegov negativan utjecaj na konkurentnost gospodarstva, sektora i poduzeća. U prilog tome je priprema legislative Europskog parlamenta (EP, 2017) čiji rezultati anketa ukazuju kako oko $80 \%$ ispitanika ( $\mathrm{n}=27901$ ) smatra kako EU treba učiniti više u borbi protiv terorizma. Slični rezultati mogu se pronaći u istraživanju Eurobarometra (2017) naziva „Budućnost Europe“ gdje je terorizam drugi najčešće isticani problem odmah nakon imigracije $(n=27768)$. Zainteresiranosti javnosti naročito pridonose ekonomski uzroci i posljedice međunarodnog terorizma (11. rujan, Madrid, London, Pariz itd.) kao i razni ekonomski aspekti nejedinstvene sigurnosne politike.

Dosadašnja analiza ekonomskih posljedica terorističkih djelovanja nije u dovoljnoj mjeri pridonijela kreiranju ekonomskih modela namijenjenih mjerenju učinka terorističkih aktivnosti na izvoznu konkurentnost zemalja. Utjecaj terorizma na FDI (inozemna direktna ulaganja) također predstavlja insuficijentno istraženu temu. Iz toga proizlazi teorijsko i praktično opravdanje provedenog znanstvenog istraživanja.

Izravna strana ulaganja (FDI) predstavljaju jedan od ključnih generatora gospodarskog rasta. Prema Buckleyu et al. (2002), akumulacija kapitala i povećanje ljudskog kapitala kroz obrazovanje, obuku i nova rukovodstva predstavljaju pozitivne karakteristike priljeva izravnih stranih ulaganja. Falki (2009) tvrdi kako FDI osnažuje gospodarski rast zemalja u razvoju, dok Younus et. al (2014) dodaju pozitivan utjecaj FDI-ja na gospodarski rast. S druge strane, Gunby et al. (2017) ističu puno manji utjecaj FD na rast gospodarskog rasta Kine u odnosu na očekivano. Alvarado et al. (2017) dokazuju pozitivan, signifikantan učinak FDI-ja u primjeru visoko razivjenih zemalja, ali ne u slučaju zemalja s više-srednjim prihodima. Neoklasični modeli rasta pokazuju kako FDI potiču stvaranje kapitala, jačanje proizvodnje i gospodarskog rasta (pod određenim uvjetima). Izravna strana ulaganja obično podrazumijevaju i transfer tehnologije. Učinkovitost FDI-ja može biti postojeća ne samo kratkoročno, već i dugoročno (Roman and Padureanu, 2012). Bez obzira na to, odljev izravnih stranih ulaganja ponekad može biti štetan. Posebno u slučaju domaćeg gospodarstva koja se suočava s padom gospodarskog rasta (Melnyk et. al, 2014).

Terorističke aktivnosti smanjuju sigurnost i povjerenje ulagača u zemlje izložene terorističkim aktivnostima, smanjujući priljev izravnih stranih ulaganja. S druge strane, troškovi protuterorističke sigurnosti opterećuju gospodarstvo i smanjuju gospodarski potencijal (Bezić et.al., 2016; Galović et al., 2018). Ekonomski učinci međunarodnog terorizma evidentni su kratkoročno i dugoročno. U kratkom roku, terorizam rezultira materijalnim gubicima, žrtvama i stvaranjem negativne investicijske klime. Dugoročno gledano, međunarodni terorizam utječe na povećanje cijena zbog povećane potrošnje na 
nacionalnu sigurnost $\mathrm{i}$ antiterorističke aktivnosti. Negativne posljedice mogu se vidjeti $\mathrm{u}$ gospodarskim sektorima kao što su turizam, prometni sektor itd. Na taj način, troškove sigurnosti snose svi korisnici proizvoda na međunarodnom tržištu, uz zemlju kojoj prijeti terorizam.

Rad odgovara na pitanje koliko terorističke aktivnosti negativno utječu na stanje priljeva FDI-ja ispitane grupe tranzicijskih zemalja globalnog gospodarstva. Implementacijom ekonometrijskih alata, cilj rada je ispitati utjecaj terorističkih aktivnosti na zalihe priljeva FDI-ja 16 tranzicijskih zemalja svijeta u razdoblju od 2000. do 2016. godine. Očekivani rezultat provedenog znanstvenog istraživanja dokazuje kako terorističke aktivnosti negativno djeluju na stanje FDI priljeva tranzicijskih zemalja svjetskog gospodarstva.

Rad se temelji na hipotezi u kojoj teroristički incidenti imaju negativan utjecaj na stanje FDI priljeva tranzicijskih zemalja svijeta. Može se pretpostaviti kako teroristički incidenti imaju određen negativan utjecaj na izravna strana ulaganja, ali su manje značajni u odnosu na institucionalne čimbenike. Glavni cilj istraživanja je testirati utjecaj institucionalnih, ekonomskih, prirodnih i terorističkih dimenzija na stanje FDI priljeva 16 tranzicijskih zemalja svijeta. Na kraju rada, predložene su mjere za poboljšanje razine sigurnosti za stvaranje sigurno ulagačkog okruženja i povećanja međunarodne konkurentnosti razvijenih zemalja svijeta.

Istraživanje se sastoji od pet međusobno povezanih dijelova. Nakon uvoda, u drugom dijelu istraživanja predstavljena su prethodna istraživanja koja se odnose na FDI tokove i terorističke aktivnosti. Metodološki okvir istraživanja prikazan je u trećem

dijelu. Četvrti dio istraživanja obuhvaća rezultate empirijskog istraživanja. Peti dio istraživanja sadrži prijedloge i preporuke te zaključna razmatranja.

\section{DOSADAŠNJA ISTRAŽIVANJA}

Naredni dio radio sažima provedena istraživanja o terorizmu i njegovim ekonomskim implikacijama. Znanstvena istraživanja dokaz su sve veće usmjerenosti znanstvenika u proučavanju utjecaja terorizma na nacionalnu sigurnost i FDI tokove.

Istraživanja autora svjedoče, kako je već rečeno, o rastućem zanimanju znanstvenika u području proučavanja utjecaja terorizma na konkurentnost (Enders i Sandler, 1996; Tavares, 2004, Abadie i Gandeazaba, 2003; Volker i Schumacher, 2004; Drakos, 2004. Ito et. al 2004; Blomberg i Mody; 2005; Tarzi, 2005, Eckstein i Tsiddon; 2004). S druge strane, znanstvena istraživanja Li-ja (2006) Younas-a (2011) Ali i Fiess-a (2010) Quyang i Rajan-a (2016) Powers-a i Choi-ja (2012), Okada-e (2013), Mascarenhas-a i Sandler-a 
(2014), Efobi-ja i Asongu-a (2015) nisu potvrdila signifikantan utjecaj terorizma na konkurentnost gospodarstva, valja istaknuti istraživanja poput.

Određen broj istraživanja razmatra direktan odnos između terorizma i FDI tokova. Primjerice, Busse i Hefeker (2007) proveli su istraživanje u kojem ističu kako politička stabilnost, konflikti, terorizam utječu na priljeve FDI-ja. Shahrestani i Anaraki (2008) potvrđuju statistički značajan utjecaj na gospodarski rast, FDI i produktivnost. Bezić, Galović i Mišević (2016) ispitali su učinke terorizma na FDI priljeve 29 zemalja članica EU i EEA od 2000. do 2013. godine. Njihovi rezultati ukazuju na pozitivan i statistički značajan utjecaj terorizma na FDI priljeve po glavi stanovnika. Galović et.al. (2018) ispitao je utjecaj terorizma na FDI priljeve i odljeve 36 razvijenih zemalja svjetskog gospodarstva u razdoblju od 2000. do 2016. godine. Autori ističu negativan, statistički signifikantan utjecaj terorizma na stanje FDI priljeva, ali nesignifikantan utjecaj na FDI odljeve razvijenih zemalja svijeta.

Gries et al. (2011) istražili su odnos između ekonomski performansi i terorizma za 18 latinskih zemalja i potvrdili vezu između terorizma i ekonomskog rasta koji se razlikuje prema razvijenosti zemalja. Younas (2015) zaključuje kako je terorizam negativan čimbenik gospodarskog rasta i FDI-ja. Ak et al. (2015) analizirali su povezanost između terorizma i gospodarskog rasta gdje su potvrdili inverznu vezu između terorizma i ekonomskog rasta. Filer i Stanišić (2016) ističu negativni učinak terorističkih incidenata na FDI priljeve u odnosu na portfolio ulaganja i vanjski dug. S druge strane, postoje istraživanja koje ne potvrđuju utjecaj terorizma na konkurentnost.

Enders et. al. (2006) ističe negativan utjecaj terorizma na FDI za zemlje koje nisu članice OECD-a. Li (2006) ne pronalazi značajniju interakciju između terorističkih napada i FDI priljeva. Younas et al. (2011) zaključuju kako domaći i međunarodni sukobi nisu determinante FDI priljeva. Ali i Fiess (2010) potvrđuju veći utjecaj prava intelektualnog vlasništva nego terorizma na FDI. Quyang i Rajan (2016) dodaju kako teroristički incidenti nemaju utjecaj na spajanja i preuzimanja poduzeća.

\section{METODOLOGIJA}

U ovom radu utjecaj terorizma na stanje priljeva FDI-ja tranzicijskih zemalja mjeri se primjenom sistemskog GMM (Generalized Method of Moments) procjenitelja dinamičnog panela u dva koraka. Najprikladniji okvir za dobivanje procjena u kontekstu navedene problematike jest dinamički panel (Arellano i Bond, 1991; Arellano i Bover, 1995; Blundell i Bond, 1998) koji predstavlja često korištenu metodu grupe GMM procjenitelja. Posebnost metode ogleda se u nepristranim i konzistentnim procjenama parametara putem instrumenata. 
Arellano-Bond (Arellano i Bond 1991) i Arellano-Bover/Blundell-Bond (Arellano i Bover 1995; Blundell i Bond 1998) dinamčki panel procjenitelji dobivaju na većem značaju zbog svojih unaprijeđenih karakteristika u odnosu na statične modele. Potrebno je zadovoljiti uvjete poput dinamiziranja zavisne varijable koja ovisi o prethodnim realizacijama, nezavisnih varijabli koje nisu nužno egzogene (u kontekstu njihove korelacije s prošlim i tekućim realizacijama pogreške), pojedinačnih vremenskinepromjenjivih učinaka kao i pojave heteroskedastičnosti i autokorelacije.

Temeljem GMM metode razvijena su dva oblika dinamička procjenitelja; diferencirani GMM procjenitelj (Arellano i Bond, 1991) i sistemski GMM procjenitelj (Arellano i Bover, 1995; Blundell i Bond, 1998). Diferencirani i sistemski GMM procjenitelji stvoreni su za potrebe dinamičke panel analize i imaju određene pretpostavke procesa generiranja podataka (Roodman, 2009) koje treba imati na umu a to je da:

- $\quad$ pojava mora biti dinamičke prirode, s realizacijom sadašnje zavisne varijable koja je pod utjecajem varijable iz prethodnih razdoblja,

- postoji mogućnost autonomno raspoređenih pojedinačnih vremenskinepromjenjivih učinaka. Takva situacija suprotna je regresijskom modelu vremenskih presjeka;

- neke od regresorskih varijabli mogu biti endogene,

- idiosinkrazijski poremećaji (osim vremenski-nepromjenjivih učinaka) imaju specifične oblike heteroskedastičnosti, autokorelacije i

- idiosinkrazijski poremećaji su nekorelirani između pojednih varijabli.

Dinamički model s samo jednom vremenski pomaknutom (lagiranom) varijablom može biti prikazan na sljedeći način:

$$
y_{i t}=\beta y_{i t-1}+u_{i}+v_{i t},|\beta|<1
$$

gdje je yit vrijednost zavisne varijable i u razdoblju t; yt-1 je zavisna varijabla i s pomakom (lagom) za jedno razdoblje; $u_{i}$ jesu pojedinačni vremenski-nepromjenjivi učinci, a vit je slučajna pogreška. Pojedinačni učinci tretiraju se kao stohastički, a daljnja pretpostavka ključna za konzistentnost modela jest da su pogreške vit serijski nekorelirane. Pojedinačni vremenski-nepromjenjivi učinci inicijalno su povezani s prethodnim utjecajem zavisne varijable modela što ukazuje na spomenuti problem endogenosti.

Međutim, u slučaju odsutnosti serijske korelacije (autokorelacije) u slučajnoj pogrešci, vremenski pomaknute (lagirane) razlike odnosno pomaci endogenih varijabli 
mogu se koristiti kao instrumenti modela (Arellano i Bond, 1991; Greene, 2005; Stojčić et al. 2011; Stojčić i Hashi, 2011; Stojčić et al., 2012).

Standardna pogreška i pripadajuća t statistika koeficijenta mogu biti izračunate primjenom delta metode. Međutim, potrebno je imati u vidu kako su dobiveni rezultati dugoročnih koeficijenata valjani uz postojanje pretpostavke sistemske stabilnosti. Može se zaključiti kako prikazana GMM metodologija i njene karakteristike imaju svoju teoretsku i empirijsku opravdanost u kontekstu mjerenja utjecaja terorizma na stanje priljeva FDI tranzicijskih zemalja svijeta.

Istraživanje ispituje značajnost utjecaja terorizma na stanje FDI priljeva po glavi stanovnika (per capita) tranzicijskih zemalja svijeta. Vrijednosti FDI priljeva per capita transformirane su u prirodni logaritam. Ispituje se vidljiv utjecaj prirodnih katastrofa na stanje FDI priljeva po stanovniku. Također se pretpostavlja da ekonomska varijabla BDPa po stanovniku ima određeni učinak u kontekstu povećanja stanja priljeva FDI-ja po stanovniku. Institucionalne varijable učinkovitost vlade i borba protiv korupcije imaju očekivani pozitivan predznak i očigledan utjecaj na stanje FDI priljeva tranzicijskih zemalja. FDI je proces koji se razvija tijekom vremena. Dokazivanje gore navedenih predviđanja može dati odgovor na pitanje značaja utjecaja terorizma na FDI priljeve tranzicijskih zemalja svijeta. Ove pretpostavke empirijskog dijela bit će podvrgnute ekonometrijskom ispitivanju kako bi se potvrdila glavna hipoteza istraživanja. Na temelju dva odvojena modela odabrane su i testirane relevantne varijable. Ekonometrijski modeli kreirani su kako slijedi:

$$
\begin{aligned}
& \text { LNFDIPCinwardstock }_{i t}=\beta_{0}+\beta_{1} \text { LNFDIPCinw }(-1)_{i(t-1)}-\beta_{2} \text { Incidents }_{i t}-
\end{aligned}
$$

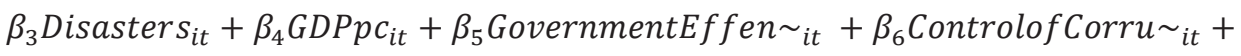

$$
\begin{aligned}
& \sum_{t=2002}^{2016} \text { year }_{t}+u_{i t}+v_{i t}
\end{aligned}
$$

Stanje priljeva FDI-a po stanovniku (LNFDIPCinwardstock) odabrana je kao zavisna varijabla u ekonometrijskom modelu (2). Stanje FDI-ja je akumulirana vrijednost koja se drži na kraju referentnog razdoblja (obično godinu ili kvartal). Podaci su preuzeti iz referentne baze podataka UNCTAD (2019). Argumenti koji podupiru izbor zavisne varijable priljeva izravnih stranih ulaganja mogu se naći u empirijskim istraživanjima koja potvrđuju negativan utjecaj terorističkih napada na izravna strana ulaganja. Filer i Stanišić (2016) analizirali su utjecaj terorizma na priljev kapitala u 160 zemalja u razdoblju od 25 godina. Autori zaključuju da teroristički napadi mogu značajno smanjiti tijek izravnih stranih ulaganja bez utjecaja na inozemni dug i investicijski portfelj. Sljedeće varijable odabrane su kao neovisne varijable modela, uključujući prirodni logaritam stanja priljeva FDI-ja po stanovniku iz prethodne godine (LNFDIPCinw (-1)), broj incidenata (Incidents), BDP po glavi stanovnika (GDPpc), institucionalne varijable 
- učinkovitost vlade (GovernmentEffe $\sim$ ), borba protiv korupcije (ControlofCorru ) te prirodne katastrofe (Disasters). LNFDIPCinw(-1) predstavlja stanje FDI priljeva po stanovniku u prethodnoj godini i, istodobno, vremenski promjenjivu varijablu.

Druga nezavisna varijabla je varijabla Incidents koja označava ukupan broj terorističkih napada, tj. incidenata. Varijabla incidenata je izražena u apsolutnim vrijednostima. Ova kategorija izračunava se kao zbroj ozlijeđenih osoba i smrtnih slučajeva od terorističkih napada. Podaci su prikupljeni iz baze podataka Global Terrorism Database (2019). Brojne empirijske studije (Kang i Lee, 2007; Agrawal, 2011; Bandyopadhyay i sur. 2011; Shahbaz i sur., 2013; Bezić i sur., 2016; Filer i Stanišić, 2016, Bezić et al., 2016; Galović et al. 2018) uključuju broj terorističkih incidenata i / ili žrtve terorizma kao nezavisne varijable modela.

Provedena istraživanja općenito potvrđuju negativan utjecaj terorizma na izravna strana ulaganja. Stoga je u ovoj studiji odabrana varijabla Incidents, koja mjeri utjecaj terorizma na stanje priljeva tranzicijskih zemalja svijeta. Model uključuje ekonomsku varijable BDP po stanovniku $(G D P p c)$ za tranzicijske zemlje svijeta. Vrijednosti BDP-a po stanovniku promatranih zemalja prikupljene su iz statističke baze podataka UNCTAD-a (2019) i izražene su u konstantnim cijenama (2010. godina). Vrijednosti BDP-a početno su denominirane u američkim dolarima. Institucionalne varijable učinkovitost vlade (GovernmentEffe $\sim$ ) i borba protiv korupcije (ControlofCorru ) preuzete su iz baze Svjetske banke World Governance Indicators (2019) i izražene su u relativnim vrijednostima. Ove varijable su od velikog značaja za razvoj tranzicijskih zemalja. Ekonometrijski izračun uključuje varijablu prirodnih katastrofa Disasters čiji su podaci preuzeti iz International Disasters Database (2019). Ista varijabla izražena je u apsolutnim vrijednostima. Varijabla prirodnih katastrofa uzeta je kao nezavisna varijabla u istraživanjima autora Filer i Stanišić (2016) koji potvrđuju negativan utjecaj prirodnih katastrofa na izravna strana ulaganja. Varijabla $u$ označava pojedinačne vremenski-nepromjenjive učinke, dok je $v$ slučajna pogreška modela.

Empirijski dio istraživanja temelji se na sekundarnom istraživanju autora. Rezultati istraživanja odnose se na razdoblje od 2000. do 2016. godine. Ekonometrijski model sastoji se od ukupno 16 tranzicijskih zemalja među kojima su Albania, Armenija, Azerbejdžan, Bjelorusija, Bosna i Hercegovina, Gruzija, Kazakhstan, Kirgistan, Crna Gora, Sjeverna Makedonija, Moldavija, Rusija, Srbija, Tadžikistan, Turkmenistan i Ukrajina. Klasifikacija analiziranih zemalja preuzeta je iz statističke baze UNCTADA (2019). 


\section{REZULTATI ISTRAŽIVANJA}

Primjenom dinamičkog modela, potencijalni problemi endogenosti i izmjerene pogreške mogu se eliminirati korištenjem instrumenata, tj. vremenskih pomaka (lagova) zavisne varijable. Implementacija dinamičkog panela eliminira probleme koji mogu utjecati na pouzdanost i procjenu rezultata empirijske analize. Inicijalno se provodi dijagnostika modela, a utjecaj će se testirati odabirom dinamičkog panela. Signifikantnost utjecaja terorističkih incidenata i drugih nezavisnih varijabli na stanje priljeva FDI ispitan je korištenjem sistemskog GMM procjenitelja u dva koraka.

Ekonometrijska analiza se provodi na primjeni ekonometrijskog softvera GRETL. Rezultati prate utjecaj odabranih nezavisnih varijabli stanja priljeva FDI-ja po stanovniku iz prethodne godine (LNFDIPCinw(-1)), broja incidenata (Incidents), BDP-a po glavi stanovnika $(G D P p c)$, institucionalne varijable - učinkovitost vlade (GovernmentEffe $\sim$ ), borba protiv korupcije (ControlofCorru $\sim$ ) te prirodne katastrofe (Disasters). Detaljan ispis rezultata dvostupanjskog GMM procjenitelja sustava nalazi se u tablici A1 (vidjeti Dodatak).

Tablica 1. pokazuje utjecaj terorizma i ostalih varijabli na stanje priljeva FDI-ja u 16 tranzicijskih zemalja svijeta. Rezultat Wald testa ukazuje na zadovoljavajuću eksplanatornu snagu varijabli. Signifikantnost testa je također potvrđena. Rezultat ekonometrijske dijagnostike pokazuje kako je model specificiran na odgovarajući način. Modeli su prikladni za ekonometrijsko testiranje utjecaja nezavisnih varijabli na zavisnu varijablu stanja priljeva FDI-ja. Dobivena vrijednost (Prob>chi2) Sarganova testa iznosi 1.0000 i veća je od 0,05, što znači kako model prihvatljiv i validan. Arellano-Bondov test koristi se za ispitivanje postojanja autokorelacije prvog (AR1) i drugog reda (AR2) u prvim razlikama jednadžbe. Nadalje, rezultat Arellano-Bondovih (2) testa ne ukazuje na prisutnost autokorelacije drugog reda zbog većeg koeficijenta $(0,14)$ od dopuštene granice od 0,05 . Stoga su nulta hipoteza o autokorelaciji drugog reda je u potpunosti prihvaćena. Koeficijenti imaju očekivane znakove i zadovoljavajuću statističku značajnost. 
Tablica 1. Rezultati dinamičkog panela sistemskog GMM procjenitelja u dva koraka od 2000. do 2016. (zavisna varijabla LNFDIPCinwardstock)

\begin{tabular}{|l|l|}
\hline NEZAVISNE VARIJABLE & VRIJEDNOST \\
\hline $\begin{array}{l}\text { Vremenski varijabla } \\
\text { zavisna } \\
\text { LNFDIPCinw(-1) }\end{array}$ & $0,126564^{* *}$ \\
\hline Incidents & $-0,000409223^{*}$ \\
\hline Disasters & $-0,121478^{* * *}$ \\
\hline GDPpc & $0,000270567^{* * *}$ \\
\hline GovernmentEffe & $0,408798^{*}$ \\
\hline ControlofCorru & $0,539711^{* *}$ \\
\hline Constant & $5,70387 * * *$ \\
\hline DIJAGNOSTIKA MODELA & VRIJEDNOST \\
\hline Broj opažanja & 209 \\
\hline Broj instrumenata & 133 \\
\hline Wald test & 1126,46 \\
\hline Prob>chi2 & 0.000 \\
\hline Sargantest & 14,6879 \\
\hline Prob>chi2 & 1.0000 \\
\hline $\begin{array}{l}\text { Arellano-Bond test u prvim } \\
\text { diferencijama AR(1) }\end{array}$ & $-2,80525$ \\
\hline Prob>chi2 & 0,0050 \\
\hline $\begin{array}{l}\text { Arellano-Bond test u prvim } \\
\text { diferencijama AR(2) }\end{array}$ & 0,8850 \\
\hline Prob>chi2 & \\
\hline
\end{tabular}

Izvor: Izračun autora

Napomena: P-vrijednosti u zagradama i oznakama *** označavaju razinu do $1 \%$ signifikantnosti. P-vrijednosti u zagradama i oznakama ** $\mathrm{i} *$ označavaju razinu do $2 \%$ odnosno $10 \%$ signifikantnosti.

Nakon dijagnostike modela, slijedi interpretacija rezultata ekonometrijskog modela. Može se uočiti pozitivan i signifikantan koeficijent vremenski pomaknute (lagirane) zavisne varijable, što potvrđuje tezu da su trenutne vrijednosti pozitivno 
povezane s prijašnjim realizacijama. Štoviše, magnituda koeficijenta govori da $1 \%$ povećanje vrijednosti koeficijenta varijable prethodnog razdoblja LNFDIPCinw(-1) rezultira rastom od $0,12 \%$ u tekućem razdoblju uz uvjet konstantnosti ostalih varijabli modela. Zavisna varijabla LNFDIPCinwardstock smanjit će za $0,0004 \%$, ako se broj incidenata (Incidents) poveća za $1 \%$, uz uvjet ceteris paribus. Poštivajući uvjet konstantnosti ostalih varijabli modela, može se zaključiti da rast varijable prirodnih katastrofa (Disasters) od $1 \%$ rezultira smanjenjem zavisne varijable LNFDIPCinwardstock od $0,12 \%$. Ako se BDP po glavi stanovnika poveća za $1 \%$, koeficijent stanja priljeva FDI-ja po glavi stanovnika, povećat će se za $0,0002 \%$ uz uvjet da se ostale varijable drže konstantnima. Varijabla LNFDIPCinwardstock povećat će se za $1 \%$ ako se učinkovitost vlade poveća za $0,40 \%$ uz uvjet konstantnosti ostalih varijabli modela. Koeficijent stanja priljeva FDI-ja po glavi stanovnika povećat će se za $1 \%$, ako se borba protiv korupcije poveća za $0,40 \%$ uz uvjet ceteris paribus.

Kontrola korupcije i učinkovitost vlade i pokazale su se kao varijable $\mathrm{s}$ najizraženijim utjecajem na FDI promatranih tranzicijskih zemalja. Drugim riječima, magnituda koeficijenta govori da $1 \%$ povećanje vrijednosti koeficijenta varijable ControlofCorru rezultira rastom od $0,53 \%$ (uz uvjet konstantnosti ostalih varijabli) dok magnituda koeficijenta pokazuje kako $1 \%$ povećanje vrijednosti koeficijenta varijable GovernmentEffe rezultira rastom od $0,40 \%$ uz uvjet konstantnosti ostalih varijabli modela.

Zaključno, statistička signifikantnost je potvrđena kod svih testiranih varijabli modela u slučajevima $1 \%, 2 \%$ i $10 \%$ signifikantnosti. Pozitivan utjecaj nezavisnih na zavisnu varijablu zabilježen je u okviru svih varijabli osim u slučaju varijable terorističkih incidenata (Incidents) i prirodnih katastrofa (Disasters).

\section{ZAKLJUČNA RAZMATRANJA}

Temeljem rezultata potvrđuje se temeljna hipoteza istraživanja u kojoj teroristički incidenti imaju negativan utjecaj na stanje FDI priljeva tranzicijskih zemalja svijeta. Štoviše, potvrđeno je kako teroristički incidenti imaju određen negativan utjecaj na izravna strana ulaganja, ali su manje značajni u odnosu na institucionalne čimbenike. Iz priloženog se može vidjeti kako institucionalni čimbenici poput učinkovitosti vlade i borbe protiv korupcije najviše utječu na stanje priljeva FDI-ja tranzicijskih zemalja svijeta. Takve teze potvrđuju činjenicu u kojoj tranzicijske zemlje, ako žele biti konkurentnije, moraju biti institucionalno uređene. Inozemni kapital bježi od nestabilnosti, a nestabilnost je svojstvena za neuređene zemlje. Ostvarena vrijednost 
priljeva FDI-ja iz prethodnog razdoblja može biti pokazatelj konkurentnosti zemlje u privlačenju FDI-ja u tekućem razdoblju.

Drugim riječima, ako je (tranzicijska) zemlja uspostavila učinkovite zakonodavno, političko stabilno okruženje ima rastuće tržište i ostvaruje gospodarski rast onda će biti atraktivna za ulagače ne samo u prošlosti i sadašnjosti, već i u budućnosti. Prirodne katastrofe na četvrtom su mjestu po intenzitetu utjecaja na stanje priljeva FDIja tranzicijskih zemalja. Prirodne katastrofe mogu imati akutne posljedice na gospodarske sektore (npr. turizam), ali i na gospodarstvo u cjelini.

Rezultati takvog karaktera nestabilnosti obeshrabruje inozemne ulagače $u$ budućim ulaganjima, ali utječe na zamrzavanje tj. povlačenje sadašnjih direktnih inozemnih ulaganja. Sukladno rezultatima, terorizam, uz BDP po glavi stanovnika, ima najmanji utjecaj na priljeve FDI-ja u testiranim tranzicijskim zemljama svijeta.

Utjecaj terorističkih napada na priljev FDI-ja tranzicijskih zemalja svijeta analizira se primjenom sistemskog GMM procjenitelja u dva koraka dinamičke panel analize. Usporedbom prednosti i nedostataka potvrđena je prikladnost GMM procjenitelja u okviru analize utjecaja na priljeve FDI-ja. Odabirom funkcijskog oblika, procjene GMM procjenitelja dinamičkog panela u dva koraka, interpretacijom dobivenih rezultata, prihvaćene su dane hipoteze istraživanja i izvedeni su relevantni zaključci.

Zemlje primateljice FDI-ja trebaju predvidjeti promjene do kojih dolazi zbog povećanja njihovog političkog rizika. Rast političkog rizika zbog geopolitičke krize u tim zemljama negativno utječe na investicijske planove nositelja izravnih stranih ulaganja i uzrokuje usporavanje njihovog rasta. Negativne posljedice terorističkih incidenata ne motiviraju investitora, a to je ključni element u jačanju tokova izravnih stranih ulaganja. Primjena rezultata ovog istraživanja može doprinijeti jasnijoj percepciji utjecaja terorizma na priljeve izravnih stranih ulaganja. Ignoriranje mogućnosti pojave terorističkih aktivnosti dugoročno negativno utječe na razvoj zemalja.

\section{LITERATURA:}

1. Ak, M. Z., Aydın, M. K., Dinar, M. (2015). “Terör ile Büyüme Arasındaki İlişki: Literatür İncelemesi” Bilgi, Vol. 31, pp. 1-16. Dostupno na: <https:/www. researchgate.net/publication/301205003>.

2. Abadie, G. Gardeazabal, J. (2003) "The economic costs of conflicts: A case study of the basque country", The American Economic Review, Vol. 93, No. 1, pp.113132, doi: 10.3386/w8478.

3. Agrawal, S. (2011) "The Impact of Terrorism on Foreign Direct Investment: Which Sectors are More Vulnerable?”, CMC Senior Theses, Paper 124, dostupno 
na:

http://scholarship.claremont.edu/cgi/viewcontent.cgi $?$ article $=1184 \&$ context $=\mathrm{cm}$ c theses.

4. Ali F., Fiess N. (2010) „Do Institutions Matter for Foreign Direct Investment?“, Open Economies Review, Vol. 21, No. 2, pp. 201 - 219, doi: 10.1007/s11079010-9170-4

5. Alvarado, R., Iñiguez, M., \& Ponce, P. (2017). „Foreign direct investment and economic growth in Latin America“. Economic Analysis and Policy, 56, 176-187, doi: https://doi.org/10.1016/j.eap.2017.09.006

6. Arellano, M., Bond, S. (1991) "Some tests of specification for panel data: Monte Carlo evidence and an application to employment equations", The Review of Economic Studies, Vol. 58, No. 2. pp. 277-297, doi: 10.2307/2297968.

7. Arellano, M., Bover, O. (1995) "Another Look at the Instrumental Variable Estimation of Error-Components Model", Journal of Econometrics, Vol. 68, No.1, pp. 29-51, doi: 10.1016/0304-4076(94)01642-d.

8. Bandyopadhyay, S., Sandler, T., Younas, J. (2011) "Foreign direct investment, aid, and terrorism: an analysis of developing countries", Federal Reserve Bank of St. Louis, Working Paper 2011-004A, doi: 10.2139/ssrn.1745142.

9. Bezić, H., Galović, T., Mišević, P. (2016) „The Impact of Terrorism on the FDI of the EU and EEA Countries“, Zbornik radova Ekonomskog Fakulteta u Rijeci: časopis za ekonomsku teoriju i praksu/Proceedings of Rijeka Faculty of Economics: Journal of Economics and Business, Vol. 34, No. 2, pp. 333-362, doi: 10.18045/zbefri.2016.2.333

10. Blomberg, B., Moby, A. (2005) "How Severly Does Violence Deter International Investment?", Claremont Colleges Economics Departments, Working Paper 2005-01, doi: 10.2139/ssrn.722812.

11. Blundell, R., Bond, S. (1998) "Initial Conditions and Moment Restrictions in Dynamic Panel Data Models", Journal of Econometrics, Vol. 87, No.1, pp. 115143, doi: 10.1016/s0304-4076(98)00009-8.

12. Buckley P, Clegg J, Wang C, Cross A. (2002) „FDI, Regional Differences and Economic Growth: Panel Data Evidence from China“, Transnational Corporations Vol.11, pp. 115-135. doi: https://doi.org/10.1057/9780230508644_12

13. Busse, M., Hefeker, C. (2007) „Political risk, institutions and foreign direct investment", European Journal of Political Economy, 23(2): 397 - 415, doi: 10.1016/j.ejpoleco.2006.02.003

14. Drakos, K. (2004) "Terrorism-Induced Structural Shifts in Financial Risk: Airline Stocks in the Aftermath of the September 11th Terror Attacks", European 
Journal of Political Economy, Vol. 20, No. 2, pp. 435-446, doi: 10.1016/j. ejpoleco.2003.12.010.

15. Eckstein, Z., Tsiddon, D. (2004) "Macroeconomic Consequences of Terror: Theory and the Case of Israel", Journal of Monetary Economics, Vol. 51, No. 5, pp.; doi: 10.1016/j.jmoneco.2004.05.001

16. Efobi, U., Asongu, S., Beecroft, I. (2015) „Foreign direct investment, aid and terrorism: empirical insight conditioned on corruption control", African Governance and Development Institute, Working Paper No. 15/007; doi: 10.2139/ssrn.2586355

17. Enders, W., Sandler, T. (1996) "Terrorism and Foreign Direct Investment in Spain and Greece”, Kyklos, Vol. 49, No. 3, pp. 331-352, doi: 10.1111/j.14676435.1996.tb01400.x.

18. Enders, W., Sachsida, A., Sandler, T. (2006) „The impact of transnational terrorism on US foreign direct investment“, Political Research Quarterly, Vol. 59, No. 4, pp. 517 -531, doi: 10.1177/106591290605900402

19. EUROBAROMETER (2017). https://data.europa.eu/euodp/hr/data/dataset/S2131_86 1451 ENG

20. European Parliament (2017) Combating terrorism http://www.europarl.europa.eu/RegData/etudes/BRIE/2017/599269/EPRS_BRI( 2017)599269 EN.pdf

21. Falki, N. (2009). „Impact of foreign direct investment on economic growth in Pakistan“. International Review of Business Research Papers, 5(5), 110-120.

22. Filer, R.K., Stanišić, D. (2016) „The effect of terrorist incidents on capital flows“, Review of Development Economics, Vol. 20, No. 2, pp. 502 - 513, doi:10.1111/rode.12246

23. Galović, T., Bezić, H., Mišević, P. (2018) „Terrorist activities and capital flows of developed countries“, Acta oeconomica, Vol. 68, doi: 10.1556/032.2018.68.3.2

24. Global Terrorism Database (2019). http://www.start.umd.edu/gtd/

25. Greene, W.H., (2005): Econometric Analysis (5th International Edition), Prentice Hall.

26. Gries, T., Krieger, T., Meierrieks, D. (2011) “Causal Linkages Between Domestic Terrorism and Economic Growth“, Defence and Peace Economics, Vol. 22, No.5, pp. 493- 508, doi: 10.1080/10242694.2010.532943.

27. Gunby, P., Jin, Y., \& Robert Reed, W. (2017). „Did FDI Really Cause Chinese Economic Growth? A Meta-Analysis“. World Development, 90, 242-255., doi: https://doi.org/10.1016/j.worlddev.2016.10.001

28. International Disasters Database (2019): http://www.emdat.be. 
29. Ito, H., Lee, D. (2004) "Assessing the Impact of the September 11 Terrorist Attacks on US Airline Demand", Journal of Economics and Business, Vol. 57, No. 1, pp. 75-95, doi: 10.2139/ssrn.722491.

30. Kang, S. J., Lee, H. S. (2007) "Terrorism and FDI Flows: Cross-Country Dynamic Panel Estimation", Journal of Economic Theory and Econometrics, Vol. 18, No. 1, pp. 57-77, dostupno na: http://www.apeaweb.org/confer/hito05/papers/ kang_s.pdf.

31. Li, Q. (2006) „Political violence and foreign direct investment“, in Fratianni M. (ed), Regional Economic Integration, 12 (Research in Global Security Management): 225 - 249, doi: 10.1016/S1064-4857(06)12011-2

32. Mascarenhas, R., Sandler, T. (2014) „Remittances and terrorism: A global analysis, Defence and Peace Economics“, Vol. 25, No. 4, pp. 331 - 347, doi: 10.1080/10242694.2013.824676

33. Melnyk, L., Kubatko, O., Pysarenko, S. (2014) „The impact of foreign direct investment on economic growth: case of post communism transition economies", Problems and Perspectives in Management, Vol. 12, No. 1, dostupno na: https://www.researchgate.net/publication/285954368_The_impact_of_foreign direct_investment_on_economic_growth_Case_of_post_communism transition economies

34. Okada, K. (2013) ,The interaction effects of financial openness and institutions on international capital flows“, Journal of Macroeconomics, Vol. 35, pp. 131 143, doi: 10.1016/j.jmacro.2012.11.003

35. Powers, M., Choi, S.W. (2012) „Does Transnational Terrorism Reduce Foreign Direct Investment? Business - Related Versus non - Business - Related Terrorism“, Journal of Peace Research, Vol. 49, No. 3, pp. 407 - 422, doi:10.1177/0022343312436768

36. Quyang, A.Y., Rajan R.S. (2016) „Impact of terrorism on cross-border mergers and acquisitions (M\&As): Prevalence, frequency and intensity“, Open Economies Review, Article in press, 1 - 28, doi: 10.1007/s11079-016-9407-y

37. Roman, M., D., Padureanu, A. (2012) „Models of Foreign Direct Investments Influence on Economic Growth. Evidence from Romania“, International Journal of Trade, Economics and Finance, Vol. 3, No. 1, doi: 10.7763/ijtef.2012.v3.167

38. Roodman, D. (2009) "A Note on the Theme of Too Many Instruments", Oxford Bulletin of Economics and Statistics, Vol. 71, No. 1, pp. 135-158, doi: 10.1111/j.1468-0084.2008.00542.x 
39. Shahbaz, M. A., Javed, A., Amina, D., Sattar, T. (2013) "Performance Measurement of Small and Medium Enterprises (SMEs) in Pakistan", Archives of Business Research, Vol. 2, No. 3, doi: 10.14738/abr.23.320.

40. Shahrestani, H., Anaraki, N. K. (2008) „Protectivity Versus Productivity And Economic Growth: Empirical Evidence from Selected Countries“, International Business \& Economics Research, Journal, Vol. 7, No. 10, doi: 10.19030/iber.v7i10.3299

41. Tarzi, S. (2005) "Foreign Direct Investment flows into Developing Countries: Impact Location and Government Policy", Journal of Social, Political and Economic Studies, Vol. 30, No. 4, pp. 497-515, dostupno na: https://www. questia.com/library/journal/1P3-948618511/foreign-direct-investmentflowsinto-developing-countries.

42. Tavares, J. (2004) "The Open Society Assesses Its Enemies: Shocks, Disasters and Terrorist Attacks", Journal of Monetary Economics, Vol. 51, No. 5, pp. 1039-1070, doi: 10.1016/j.jmoneco.2004.04.009.

43. United Nations Conference onTrade and Development (UNCTAD) (2019). www.unctad.org

44. Volker, N., Schumacher D. (2004) "Terrorism and international trade: an empirical investigation", European Journal of Political Economy, Vol. 20, No. 2, pp. 423-433, doi: 10.1016/j.ejpoleco.2003.12.009.

45. World Governance Indicators, 2019 , https://databank.worldbank.org/reports.aspx?source=worldwide-governanceindicators

46. Younas, J. (2015). Does globalization mitigate the adverse effects of terrorism on growth?, Oxford Economic Papers, Vol. 67, No. 1, pp. 133 - 156, doi 10.1093/oep/gpu040

47. Younus, H. S., Sohail, A., \& Azeem, M. (2014) „Impact of foreign direct investment on economic growth in Pakistan“, World, 1(1), 002-005. dostupno na: http://www.premierpublishers.org/ 


\section{DODATAK}

Table A1: Sistemski GMM procjenitelj u 2 koraka

Model 4: 2-step dynamic panel, using 209 observations

Included 16 cross-sectional units

Time-series length: minimum 10, maximum 14

Including equations in levels

$\mathrm{H}$-matrix as per $\mathrm{Ox} / \mathrm{DPD}$

Dependent variable: LNFDIPCinwardstock

Asymptotic standard errors

$\begin{array}{llllll} & \text { Coefficient } & \text { Std. Error } & \mathrm{z} & \mathrm{p} \text {-value } & \\ \text { LNFDIPCinw(-1) } & 0,126564 & 0,0518671 & 2,440 & 0,0147 & * * \\ \text { const } & 5,70387 & 0,334735 & 17,04 & <0,0001 & * * * \\ \text { ControlofCorru } ~ & 0,539711 & 0,215283 & 2,507 & 0,0122 & * * \\ \text { GovernmentEffe } \sim & 0,408798 & 0,219285 & 1,864 & 0,0623 & * \\ \text { GDPpc } & 0,000270567 & 1,21278 \mathrm{e}-05 & 22,31 & <0,0001 & * * * \\ \text { Disasters } & -0,121478 & 0,0265989 & -4,567 & <0,0001 & * * * \\ \text { Incidents } & -0,000409223 & 0,000248187 & -1,649 & 0,0992 & *\end{array}$

Sum squared resid

Number of instruments $=133$

Test for AR(1) errors: $z=-2,80525[0,0050]$

Test for AR(2) errors: $z=0,14461[0,8850]$

Sargan over-identification test: Chi-square $(126)=14,6879[1,0000]$

Wald (joint) test: Chi-square(6) $=1126,46[0,0000]$ 


\title{
THE EFFECTS OF TERRORIST ATTACKS ON FOREIGN DIRECT INVESTMENTS INFLOWS IN TRANSITION COUNTRIES ${ }^{12}$
}

\author{
Tomislav Galović
}

\begin{abstract}
Summary
The main aim of the paper is to empirically measure the impact of terrorism and other (institutional, economic, natural) factors on the foreign direct investments (FDI inward stock) of transition economies in the world. Methodology includes the application of two-step system GMM (Generalized Method of Moments) estimator of dynamic panel analysis. The research covers a group of 16 countries from 2000 to 2016. Research findings confirm that terrorist incidents, economic and institutional variables affect FDI inward stock of transition economies. It can be concluded that institutional variables (Government effectiveness, control of corruption) recorded the most significant impact on the inward FDI stock in the transition economies of the global economy. From the results, we can see the international competitiveness of transition countries about the influence of the variables of terrorism and other relevant model variables on foreign direct investments (FDI).
\end{abstract}

Key words: FDI, Competitiveness, Transition Countries, Terrorism, GMM estimator.

12 Paper has been financially supported by the University of Rijeka under the project number uniri-drustv-18-16. 